\title{
ANNUAL ACTIVITY OF THE NOBLE CRAYFISH (ASTACUS ASTACUS) IN THE ORLJAVA RIVER (CROATIA)
}

\author{
FALLER M. (1), MAGUIRE I. (2), KLOBUČAR G. (2)
}

(1) K. Krešimira 34, 34000 Požega, Croatia, matejfaller@gmail.com

(2) Department of Biology, Faculty of Science, University of Zagreb, Rooseveltov trg 6, 10000 Zagreb, Croatia, E-Mail: imaguire@biol.pmf.hr, gklobuca@zg.biol.pmf.hr

Reçu le 16 juin 2005

Accepté le 5 décembre 2006

Received June 16, 2006

Accepté le 5 décembre 2006

\begin{abstract}
We studied the annual activity of the noble crayfish (Astacus astacus) at three sites along the Orljava River, in the continental part of Croatia, between August 2003 and September 2004. Each site represented the typical characteristics of the upper, middle and lower section of the river (5,24 and $37 \mathrm{~km}$ from the spring, respectively). The biggest population size was recorded on the most upstream site, with greatest structural variability of bottom, high biotic index, and the lowest mean water temperature. Males dominated in catch during the whole research period (total sex ratio was 1.77 males: 1 female). The number of caught crayfish fluctuated during the year and their activity was positively correlated with the water temperature. The crayfish catch within the two downstream sites was dramatically lower in the autumn 2004 then the year before. No obvious reason could be found; therefore we concluded that this was probably result of natural fluctuations in population. Males were significantly longer than females on all three sites. Males and females had similar percentages of injuries, mainly on claws and antennae. Crayfish were active during the whole year, even when water temperature was just $1^{\circ} \mathrm{C}$. Phases of life cycle (moulting, active cement glands, mating, hatchlings) occurred a month later in our population than in the Northern Europe populations, probably as a consequence of differences in the climate.
\end{abstract}

Key-words: Astacus astacus, life cycle, population dynamics, Croatia.

\section{L'ACTIVITÉ ANNUELLE DE L'ÉCREVISSE À PIEDS ROUGES (ASTACUS ASTACUS L.) DANS LA RIVIERE ORLJAVA (CROATIE)}

\section{RÉSUMÉ}

Nous avons étudié l'activité annuelle de l'écrevisse à pieds rouges (Astacus astacus) sur trois sites de la rivière Orljava, Croatie continentale. Les résultats présentés ici ont été obtenus d'août 2003 à septembre 2004. Chacun des sites présente les caractéristiques typiques des parties supérieure, moyenne et inférieure de la rivière $(5,24$ et $37 \mathrm{~km}$ de la source, respectivement). La population la plus importante a été enregistrée sur le site le plus élevé, où le substrat est le plus diversifié, l'indice biotique le plus grand et la température moyenne de l'eau la plus basse. Les mâles ont été prélevés dans les nasses pendant l'étude (proportion de 1,77 mâles pour 1 femelle). Le nombre d'écrevisses 
capturées a fluctué au cours de l'année et leur activité est positivement corrélée à la température de l'eau. Le nombre d'écrevisses dans les sites en aval a diminué fortement en 2004. Comme nous n'avons pas trouvé de raison évidente pour cette diminution, nous pouvons l'attribuer à la fluctuation naturelle de la population. Les mâles capturés étaient significativement plus grands que les femelles. Les blessures observées sont principalement la perte de pinces, d'antennes et de pattes. Les écrevisses étaient actives pendant l'année entière, même quand la température de l'eau était de $1^{\circ} \mathrm{C}$. Les fonctions physiologiques (la mue, le développement des glandes, la reproduction, l'éclosion des juvéniles) sont apparues un mois plus tard que dans les populations de l'Europe du Nord, probablement à cause des différences de climat.

Mots-clés: Astacus astacus, dynamique de la population, cycle annuel, Croatie.

\section{INTRODUCTION}

The noble crayfish (Astacus astacus) is one of four native European crayfish species inhabiting Croatian freshwater habitats. It is native in the Sava River and the Drava River basins, but, due to its economic value, it has also been introduced into some water bodies in the Adriatic Sea Basin (MAGUIRE and GOTTSTEIN-MATOČEC, 2004). At present, the noble crayfish is considered as a threatened species and is protected by Croatian Law (NARODNE NOVINE, 70/05, 7/06).

The life cycle of $A$. astacus has been described by different authors (CUKERZIS, 1988; ACKEFORS, 1999). The most detailed information concerning the biology of the noble crayfish exists for populations in the Northern Europe (SKURDAL and TAUGB $\varnothing$ L, 2002). Noble crayfish mate in autumn, and the length of their life cycle depends on the climate and the habitat in which they live. The breeding season begins with the temperature decline in autumn. Testes and ovaries mature between July and September (LAHTI and LINDQUIST, 1983). Mating and spawning is not fixed to a specific temperature or date, but a higher temperature delays the onset of mating. Mating takes place in autumn, during September and October (HUNER and LINDQVIST, 1986; WESTIN and GYDEMO, 1986) and usually lasts for 2 to 3 weeks. Extrusion and fertilisation of eggs depends on the time of mating and water temperature and occurs in period from a few hours to up to 6 weeks after mating. The egg development time is also influenced by temperature and may last 8-9 months for the northern crayfish populations. A cold water period $\left(<5-6^{\circ} \mathrm{C}\right)$ seems necessary to secure high egg and juvenile survival. According to CUKERZIS (1988), the hatchlings of noble crayfish are 8.5 to $9 \mathrm{~mm}$ total length. After two moults, in the third stage reaching 13-15 $\mathrm{mm}$ they look like true adults and they are adapted for solitary life.

Females reach sexual maturity at a size that ranges from $6.2 \mathrm{~cm}$ total length in localities with earlier maturity or slow growth to $8.5 \mathrm{~cm}$ total length in localities with late maturity or fast growth. Mean length of females with active cement glands stretches from 7.6 till $10.5 \mathrm{~cm}$, depending on the population. This corresponds to an age of 3-5 years. Proportion of mature females varies between different populations and years (6-97\%). Males become mature at a size of $6.0-7.0 \mathrm{~cm}$ total length (ABRAHAMSSON, 1966).

\section{MATERIAL AND METHODS}

\section{Description of sites}

The study was conducted at three sites along the Orljava River, the left tributary of the Sava River, between August 2003 and September 2004. The river is $89 \mathrm{~km}$ long, and the sites were chosen to represent the upper, the middle and the lower section of the river (distance from a spring was 5, 24 and $37 \mathrm{~km}$ respectively) (Figure 1). 


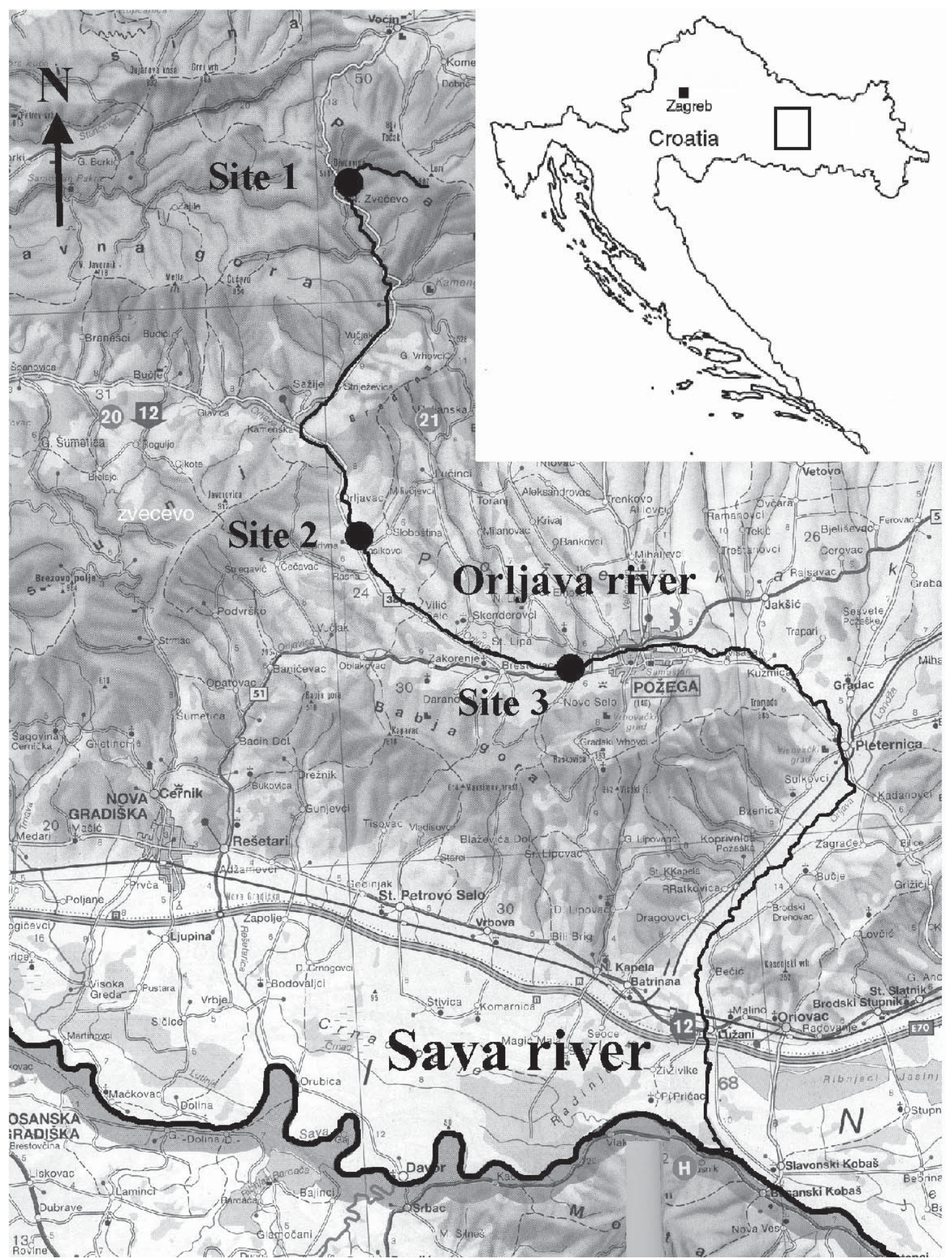

\section{Figure 1}

Position of study sites (black dots) on the Orljava River. The map was adapted from original 1:250 000 map of Croatia. Sites 1,2 and 3 correspond to upper, middle and lower part of the river, respectively.

Figure 1

Localisation des sites d'étude (points noirs) sur la rivière Orljava. La carte a été adaptée à partir d'une carte originale de la Croatie au $1: 250000$. Les sites 1, 2 et 3 correspondent aux parties supérieure, moyenne et inférieure de la rivière. 
Site 1 is a brook flowing through dense beech forest with alder trees along its banks. There is no human activity upstream that could cause pollution of the water. Site 2 is a stream flowing through agricultural area, but has a 10 to $20 \mathrm{~m}$ wide zone of alder and willow trees on the banks. Site 3 is a small river that flows through the middle of an agricultural area, downstream from few small villages, with mostly willow trees on the banks. Other characteristics of these sites are shown in Table I. In this area crayfish plague or non-indigenous crayfish species have never been recorded (MAGUIRE and GOTTSTEINMATOČEC, 2004) and there is no commercial exploitation of crayfish. Presence of crayfish was recorded on all three sites during summer and autumn of 2003 and this research was continued until September 2004.

Table I

Characteristics of study sites on the Orljava River.

Tableau I

Caractéristiques des sites d'étude sur la rivière Orljava.

\begin{tabular}{|l|c|c|c|}
\hline Characteristic & Site 1 & Site 2 & Site 3 \\
\hline Altitude [meters above sea level] & 462 & 196 & 159 \\
\hline Length of study stretch [m] & 115 & 125 & 140 \\
\hline Mean Width [m] & 3.12 & 4.86 & 9.50 \\
\hline Mean Depth [cm] & 17.9 & 50.5 & 61.4 \\
\hline Mean Velocity [ms ${ }^{-1}$ ] & 0.33 & 0.57 & 0.19 \\
\hline Percentage of substrate $<1.6 \mathrm{~cm}$ & 34 & 55 & 86 \\
\hline Percentage of substrate $1.6-15 \mathrm{~cm}$ & 38 & 31 & 5 \\
\hline Percentage of substrate $>15 \mathrm{~cm}$ & 28 & 14 & 9 \\
\hline
\end{tabular}

\section{Environmental parameters}

Water temperature was measured on each site during each survey using thermometer and Gemini Data Loggers. These temperature values were used for the analyses of differences in crayfish activity during the year. Data on the other physical and chemical parameters of water were obtained from Croatian Waters (Public company for general water management control, survey and informing upon water conditions). Their sampling site is two kilometres downstream from the Site 3, so we considered their data representative for the analyses of life conditions on that site. Data were collected once a month during the whole period of our research. Following parameters were analysed: water temperature, $\mathrm{pH}$, conductivity, alkalinity, concentration of $\mathrm{O}_{2}$, oxygen saturation, concentration of $\mathrm{NH}_{3}$, nitrites, nitrates, total, inorganic and organic nitrogen and total phosphorus (Table II). Observed difference in the water temperature, in the August 2003, measured by Croatian Waters $\left(29^{\circ} \mathrm{C}\right)$ and us $\left(16^{\circ} \mathrm{C}\right)$ must have been a consequence of probably inappropriate measurement (in the shallow, isolated part of the river) done by Croatian Waters and it did not reflect the real water temperature of the river so we have excluded it from our analyses.

Quality samples of macrozoobenthos were also taken using kick sampling net and biotic index (WOODIWISS, 1964) was calculated for each site. Values of biotic index were 10,11 , and 10 for the sites 1,2 and 3, respectively.

Information on presence of fish was obtained from local fishermen; also, occasionally, fish were caught in traps. On the Site 1, the only fish species recorded was bullhead, 


\section{Table II}

Physico-chemical parameters of water measured monthly by Croatian Waters near Site 3 from August 2003 till September 2004 (Valid N = 14).

Tableau II

Paramètres physiques et chimiques mesurés chaque mois, entre Août et Septembre 2004, par Croatian Waters $(\mathbf{N}=14)$.

\begin{tabular}{|c|c|c|c|c|}
\hline Water Parameter & Mean & Min. & Max. & Std. Dev. \\
\hline Temperature $\left[{ }^{\circ} \mathrm{C}\right]$ & 14.43 & 1 & 29 & 8.75 \\
\hline $\mathrm{pH}$ & 7.83 & 7.23 & 8.34 & 0.29 \\
\hline Conductivity $\left[\mu \mathrm{S} \mathrm{cm}^{-1}\right]$ & 372.07 & 239 & 458 & 65.83 \\
\hline Alkalinity $\left[\mathrm{mg} \mathrm{CaCO}_{3} \mathrm{dm}^{-3}\right.$ ] & 163.73 & 105 & 195 & 29.27 \\
\hline Oxygen $\left[\mathrm{mg} \mathrm{O}_{2} \mathrm{dm}^{-3}\right]$ & 10.58 & 7.95 & 13.08 & 1.56 \\
\hline Oxygen saturation [\%] & 98.00 & 82.38 & 112.95 & 6.84 \\
\hline $\mathrm{NH}_{3}\left[\mathrm{mg} \mathrm{N} \mathrm{dm}^{-3}\right]$ & 0.074 & 0.012 & 0.436 & 0.116 \\
\hline $\mathrm{NO}_{2}^{-}\left[\mathrm{mg} \mathrm{N} \mathrm{dm}^{-3}\right]$ & 0.008 & 0.002 & 0.017 & 0.004 \\
\hline $\mathrm{NO}_{3}^{-}\left[\mathrm{mg} \mathrm{N} \mathrm{dm}^{-3}\right]$ & 0.831 & 0.231 & 1.667 & 0.422 \\
\hline Total nitrogen [mg N dm${ }^{-3}$ ] & 1.632 & 0.970 & 2.921 & 0.570 \\
\hline Inorganic nitrogen [mg N dm${ }^{-3}$ ] & 0.915 & 0.250 & 1.893 & 0.473 \\
\hline Organic nitrogen [mg N dm${ }^{-3}$ ] & 0.716 & 0.318 & 1.564 & 0.380 \\
\hline Total phosphorus [mg P dm${ }^{-3}$ ] & 0.118 & 0.046 & 0.297 & 0.081 \\
\hline
\end{tabular}

Cottus gobio. On two lower sites, much higher fish abundance was observed. On the Site 2, brown trout, Salmo trutta fario and on the Site 3, chub, Leuciscus spp. were occasionally caught in traps.

\section{Crayfish trapping and processing}

We used LiNi traps (WESTMAN et al., 1978) and small, hand made ones (from PVC bottles with two funnel entrances made from plastic net mesh size $=1 \mathrm{~mm}$ ). Both trap types were baited with $(0.5 \mathrm{~cm}$ thick) sausage slices. Crayfish were captured intensively during August and September 2003, and from October 2003 to September 2004 once or twice a month, during two nights. On sites 1, 2 and 3, we used 9, 11 and 14 LiNi traps respectively. Hand-made traps were used only on the Site 1 (13 traps) because river is too deep on the two lower sites to allow successful use of this trap type. Traps were placed near banks, alternately, in $10 \mathrm{~m}$ intervals.

Each individual was sexed, cephalothoraxes length $(C L)$ and total length $(T L)$ were measured. Symptoms of diseases and some physiological characteristics (moulting stage, females with active cement glands and external eggs and crayfish with remains of spermatophores attached to the abdomen) were also recorded. Epibionts were collected once from live crayfish and determined in the laboratory as Branchiobdella parasita and/or B. pentodonta. They were found on a great number of crayfish $(93 \%, 92 \%$ and $91 \%$ of crayfish on sites 1,2 and 3 , respectively). Only one individual ( $0.1 \%$ of population) with signs of burn spot disease was found on the Site 1.

Crayfish population size was expressed as Catch Per Unit of Effort (CPUE), which represents number of caught crayfish per trap per night. Comparison of annual activity and CPUE between sites is made only with data for crayfish caught in LiNi traps, because 


\section{Table III}

Total number of crayfish caught in LiNi traps and number of trapping nights through the whole period of research on each site.

Tableau III

Nombre total d'écrevisses capturées avec des nasses LiNi et nombre de nuits de capture pendant toute l'étude pour chaque site.

\begin{tabular}{|c|c|c|c|c|c|c|c|c|c|c|}
\hline & & & Site 1 & & & Site 2 & & & Site 3 & \\
\hline $\begin{array}{c}\text { Month } \\
\text { Year }\end{array}$ & Sex & $\begin{array}{l}\text { Total N } \\
\text { (nights) }\end{array}$ & $\begin{array}{l}\min / \text { mean } \\
/ \max \text { for } \mathrm{N}\end{array}$ & $\begin{array}{l}\text { std. } \\
\text { dev. }\end{array}$ & $\begin{array}{l}\text { Total N } \\
\text { (nights) }\end{array}$ & $\begin{array}{l}\min / \text { mean } \\
/ \text { max for } \mathrm{N}\end{array}$ & $\begin{array}{l}\text { std. } \\
\text { dev. }\end{array}$ & $\begin{array}{l}\text { Total N } \\
\text { (nights) }\end{array}$ & $\begin{array}{l}\min / \text { mean } \\
/ \text { max for } \mathrm{N}\end{array}$ & $\begin{array}{l}\text { std. } \\
\text { dev. }\end{array}$ \\
\hline 8 & M & $172(10)$ & $11 / 17.20 / 23$ & 4.05 & 50(8) & $4 / 6.25 / 9$ & 1.58 & - & - & - \\
\hline 2003 & $\mathrm{~F}$ & $139(10)$ & $8 / 13.90 / 20$ & 3.75 & $33(8)$ & $3 / 4.13 / 7$ & 1.25 & - & - & - \\
\hline 9 & $\mathrm{M}$ & - & - & - & $60(7)$ & $1 / 4.57 / 13$ & 3.99 & $44(4)$ & $2 / 11.00 / 20$ & 7.75 \\
\hline 2003 & $\mathrm{~F}$ & - & - & - & $6(7)$ & 0/0.86/2 & 0.90 & $16(4)$ & $0 / 4.00 / 6$ & 2.83 \\
\hline 10 & M & $6(3)$ & $0 / 2.00 / 4$ & 2.00 & $17(3)$ & $0 / 5.67 / 13$ & 6.66 & $43(6)$ & $4 / 7.17 / 13$ & 3.54 \\
\hline 2003 & $\mathrm{~F}$ & $5(3)$ & $0 / 1.67 / 4$ & 2.08 & $9(3)$ & $2 / 3.00 / 4$ & 1.00 & $27(6)$ & $3 / 4.50 / 8$ & 2.35 \\
\hline 11 & M & $6(4)$ & $0 / 1.50 / 6$ & 3.00 & $31(4)$ & $4 / 7.75 / 11$ & 3.30 & $25(4)$ & $2 / 6.25 / 9$ & 3.40 \\
\hline 2003 & $\mathrm{~F}$ & $0(4)$ & 0/0/0 & 0 & $1(4)$ & $0 / 0.25 / 1$ & 0.50 & $0(4)$ & $0 / 0 / 0$ & 0 \\
\hline 12 & M & $0(2)$ & $0 / 0 / 0$ & 0 & $0(2)$ & $0 / 0 / 0$ & 0 & 2(2) & $1 / 1.00 / 1$ & 0 \\
\hline 2003 & $\mathrm{~F}$ & $0(2)$ & 0/0/0 & 0 & $0(2)$ & $0 / 0 / 0$ & 0 & $0(2)$ & $0 / 0 / 0$ & 0 \\
\hline 1 & M & 1(2) & $0 / 0.50 / 1$ & 0.71 & $0(2)$ & $0 / 0 / 0$ & 0 & $0(2)$ & 0/0/0 & 0 \\
\hline 2004 & $F$ & $0(2)$ & 0/0/0 & 0 & $0(2)$ & $0 / 0 / 0$ & 0 & $0(2)$ & 0/0/0 & 0 \\
\hline 2 & M & $0(2)$ & 0/0/0 & 0 & $0(2)$ & $0 / 0 / 0$ & 0 & $1(2)$ & $0 / 0.50 / 1$ & 0.71 \\
\hline 2004 & $\mathrm{~F}$ & $0(2)$ & $0 / 0 / 0$ & 0 & $0(2)$ & $0 / 0 / 0$ & 0 & $0(2)$ & $0 / 0 / 0$ & 0 \\
\hline 3 & M & $0(2)$ & $0 / 0 / 0$ & 0 & $3(2)$ & $1 / 1.50 / 2$ & 0.71 & $3(2)$ & $1 / 1.50 / 2$ & 0.71 \\
\hline 2004 & $\mathrm{~F}$ & $0(2)$ & $0 / 0 / 0$ & 0 & $1(2)$ & $0 / 0.50 / 1$ & 0.71 & $0(2)$ & $0 / 0 / 0$ & 0 \\
\hline 5 & $\mathrm{M}$ & $14(3)$ & $2 / 4.67 / 6$ & 2.31 & 2(3) & 0/0.67/1 & 0.58 & $2(3)$ & 0/0.67/1 & 0.58 \\
\hline 2004 & $\mathrm{~F}$ & $1(3)$ & $0 / 0.33 / 1$ & 0.58 & $0(3)$ & 0/0/0 & 0 & $0(3)$ & 0/0/0 & 0 \\
\hline 6 & M & $5(2)$ & $1 / 2.50 / 4$ & 2.12 & $0(2)$ & $0 / 0 / 0$ & 0 & $0(2)$ & 0/0/0 & 0 \\
\hline 2004 & $\mathrm{~F}$ & 1(2) & 0/0.50/1 & 0.71 & $0(2)$ & 0/0/0 & 0 & $0(2)$ & 0/0/0 & 0 \\
\hline 7 & $\mathrm{M}$ & - & - & - & - & - & - & $1(1)$ & $1 / 1.00 / 1$ & 0 \\
\hline 2004 & $\mathrm{~F}$ & - & - & - & - & - & - & $1(1)$ & $1 / 1.00 / 1$ & 0 \\
\hline 8 & $M$ & $9(1)$ & $9 / 9.00 / 9$ & 0 & $3(1)$ & $3 / 3.00 / 3$ & 0 & - & - & - \\
\hline 2004 & $\mathrm{~F}$ & $8(1)$ & 8/8.00/8 & 0 & $0(1)$ & $0 / 0 / 0$ & 0 & - & - & - \\
\hline 9 & M & $17(2)$ & $7 / 8.50 / 10$ & 2.12 & $0(2)$ & $0 / 0 / 0$ & 0 & $2(2)$ & $1 / 1.00 / 1$ & 1.41 \\
\hline 2004 & $F$ & $3(2)$ & $1 / 1.50 / 2$ & 0.71 & $1(2)$ & $0 / 0.50 / 1$ & 0.71 & $0(2)$ & 0/0/0 & 0 \\
\hline Total & M & 230(33) & & & 166(38) & & & $123(30)$ & & \\
\hline & $\mathrm{F}$ & $157(33)$ & & & $51(38)$ & & & $44(30)$ & & \\
\hline
\end{tabular}

only they were used on all three sites. Data about crayfish caught in hand made traps on the Site 1 are used as additional information on their life cycle. Traps were placed on the same position during the whole research period. 


\section{Data analyses}

All statistical analyses (Pearson correlations, descriptive statistics, ANOVA with Tukey test) were performed using Statistica 5.0. Results were considered statistically significant at $p<0.05$. Graphs and tables were made using MS Office Excel 2002 and Statistica 5.0.

\section{RESULTS}

During research period total of 935 (597 males and 338 females) crayfish were caught in LiNi and hand made traps. Total sex ratios (males/females) of crayfish caught in LiNi traps through the year were 1.46, 3.25 and 2.80 for sites 1, 2 and 3, respectively. Statistically described data for crayfish caught in LiNi traps are shown in Table III.

Statistically described cephalothorax length is shown in Table IV. The largest male had $7.30 \mathrm{~cm}(T L=13.69 \mathrm{~cm})$ and the largest female $5.91 \mathrm{~cm}(T L=11.78 \mathrm{~cm})$ of cephalothorax length. We recorded statistically significant difference (ANOVA) in cephalothorax length between males and females on each site (Site $1 t=5.48 p<<0.05$, Site $2 t=6.62 p<<$ 0.05 , and Site $3 t=4.86 p<<0.05$ ).

Mean cephalothorax length, both for males and females, was the smallest on the Site 1 and it increases downstream (Table IV). Males'size differed statistically significant between sites 1 and $2(t=46.23, p<<0.05)$, and sites 1 and $3(t=62.75, p<<0.05)$. Females'size was significantly different between sites 1 and $3(t=52.48, p<<0.05)$ and also between sites 2 and $3(t=22.76, p<<0.05)$.

During our research we recorded injuries mainly on claws and antennae, but also on legs, rostrum, cephalothorax and abdomen. Detailed data about injuries are shown in Table V.

CPUE and water temperatures measured during each survey are described in Table VI. CPUE was significantly positively correlated with the water temperature on the Site 1 (males $r=0.774, p=0.005$ and females $r=0.648, p=0.032$ ) (Figure 2). On the Site 2 (males $r=0.403, p=0.195$ and females $r=0.486, p=0.113$ ) and the Site 3 (males $r=$ $0.326, p=0.324$ and females $r=0.465, p=0.149$ ) correlation was positive, but statistically not significant (Figures 3 and 4).

Differences in crayfish activity (Figures 2-4) between months were analysed using ANOVA. Only statistically significant $p$ values for differences in CPUEs between months are shown in Table VII.

\section{Table IV}

Length of cephalothorax of crayfish caught in LiNi traps on each site.

\section{Tableau IV}

Longueur des céphalothorax d'écrevisses capturées avec des nasses LiNi pour chaque site.

\begin{tabular}{|l|c|c|c|c|c|}
\hline & Valid N & Mean/cm & Min./cm & Max./cm & Std. Dev. \\
\hline Males on Site 1 & 159 & 4.84 & 3.38 & 7.21 & 0.79 \\
Females on Site 1 & 106 & 4.35 & 3.34 & 5.91 & 0.55 \\
\hline Males on Site 2 & 70 & 5.60 & 3.30 & 7.12 & 0.80 \\
Females on Site 2 & 19 & 4.44 & 3.29 & 5.45 & 0.68 \\
\hline Males on Site 3 & 69 & 5.68 & 3.99 & 7.30 & 0.75 \\
Females on Site 3 & 23 & 5.20 & 4.52 & 5.72 & 0.31 \\
\hline
\end{tabular}




\section{Table V}

Percentage of damages of different parts of crayfish body caught in LiNi traps for each site.

\section{Tableau V}

Pourcentage d'animaux capturés blessés à différentes parties du corps pour chaque site.

\begin{tabular}{|l|c|c|c|c|c|c|}
\hline & \multicolumn{2}{|c|}{ Site 1 } & \multicolumn{2}{c|}{ Site 2 } & \multicolumn{2}{c|}{ Site 3 } \\
\hline Sex & males & females & males & females & males & females \\
\hline Antennae \% & 13.11 & 11.74 & 11.24 & 6.25 & 8.20 & 6.82 \\
\hline Claws \% & 15.74 & 22.17 & 17.75 & 9.38 & 9.02 & 4.55 \\
\hline Legs \% & 2.95 & 3.04 & 3.55 & 1.56 & 2.46 & 0 \\
\hline Rostrum \% & 0.98 & 0.87 & 2.96 & 0 & 1.64 & 2.27 \\
\hline Cephalothorax \% & 0.98 & 0.43 & 1.18 & 0 & 0 & 2.27 \\
\hline Abdomen \% & 3.93 & 1.30 & 3.55 & 0 & 6.56 & 9.09 \\
\hline
\end{tabular}

\section{Table VI}

Water temperature measured during trapping and CPUE of males and females for all three sites.

\section{Tableau VI}

Température mesurée pendant la capture et CPUE pour les mâles et les femelles pour chaque site.

\begin{tabular}{|l|c|c|c|c|}
\hline & Mean & Min. & Max. & Std. Dev. \\
\hline Temperature $\left[{ }^{\circ} \mathrm{C}\right]$, Site 1 & 9.16 & 0.1 & 17.0 & 6.02 \\
Temperature $\left[{ }^{\circ} \mathrm{C}\right]$, Site 2 & 10.66 & 0.9 & 17.0 & 5.70 \\
Temperature $\left[{ }^{\circ} \mathrm{C}\right]$, Site 3 & 10.42 & 1.5 & 15.8 & 5.27 \\
\hline CPUE males, Site 1 & 0.46 & 0 & 1.91 & 0.60 \\
CPUE females, Site 1 & 0.26 & 0 & 1.54 & 0.50 \\
\hline CPUE males, Site 2 & 0.25 & 0 & 0.78 & 0.30 \\
CPUE females, Site 2 & 0.07 & 0 & 0.38 & 0.12 \\
\hline CPUE males, Site 3 & 0.20 & 0 & 0.79 & 0.26 \\
CPUE females, Site 3 & 0.06 & 0 & 0.32 & 0.12 \\
\hline
\end{tabular}

The results of ANOVA (Table VII) indicated that CPUE (Figure 2) for males on the Site 1 in late summer and autumn was higher in the year 2003 (August) compared to year 2004, but differences were not significant (August $p=0.704$ and September $p=0.196$ ). Activity of males on the Site 1 was significantly higher in August 2003 compared to all the months from October 2003 till June 2004 ( $p<0.05$ ). Activity of females on the Site 1 was significantly higher in August 2003 compared to all the months from October 2003 till June 2004 ( $p<0.05$ ); also there was no significant difference recorded between August 2003 and August $2004(p=0.834)$.

On the two lower sites CPUE in the year 2004 was much lower then in the previous year (Figures 3 and 4), but results of ANOVA indicated that the differences were mainly insignificant (Table VII). On the Site 2 CPUE for females was significantly higher in August 


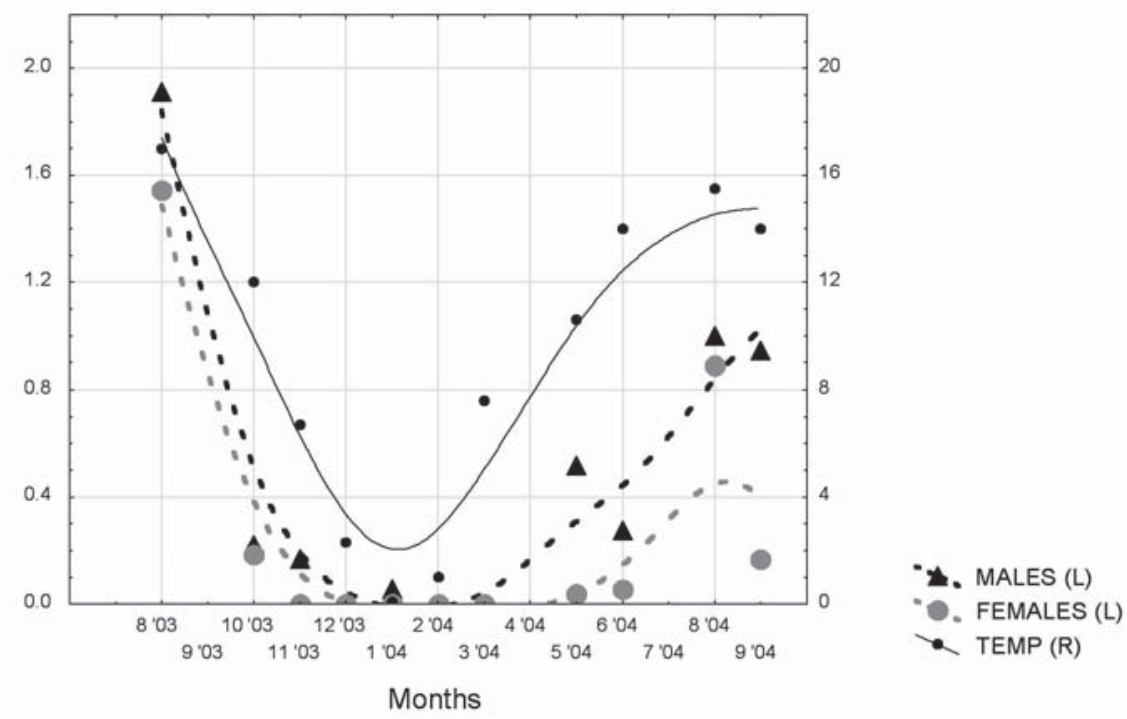

Figure 2

Relation between CPUE and the water temperature (measured during survey) on Site 1 (upper site).

Figure 2

Relation entre CPUE et température de l'eau (mesurée pendant l'étude) sur le site 1 (partie supérieure).

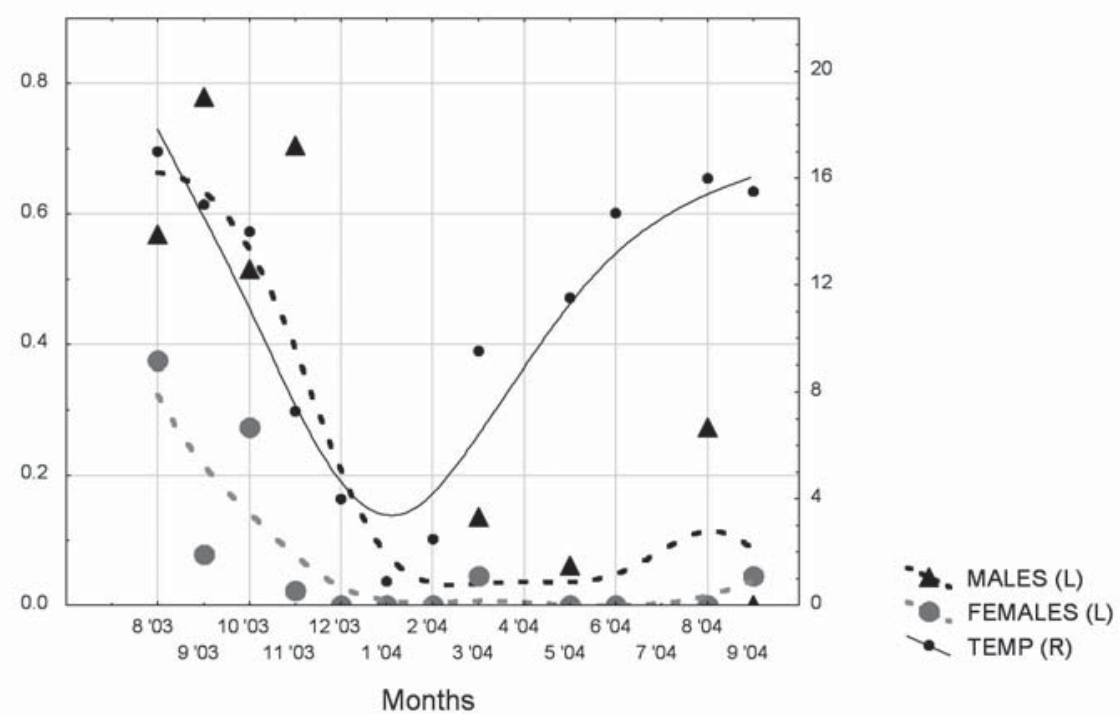

Figure 3

Relation between CPUE and the water temperature (measured during survey) on Site 2 (middle site).

Figure 3

Relation entre CPUE et température de l'eau (mesurée pendant l'étude) sur le site 2 (partie moyenne). 


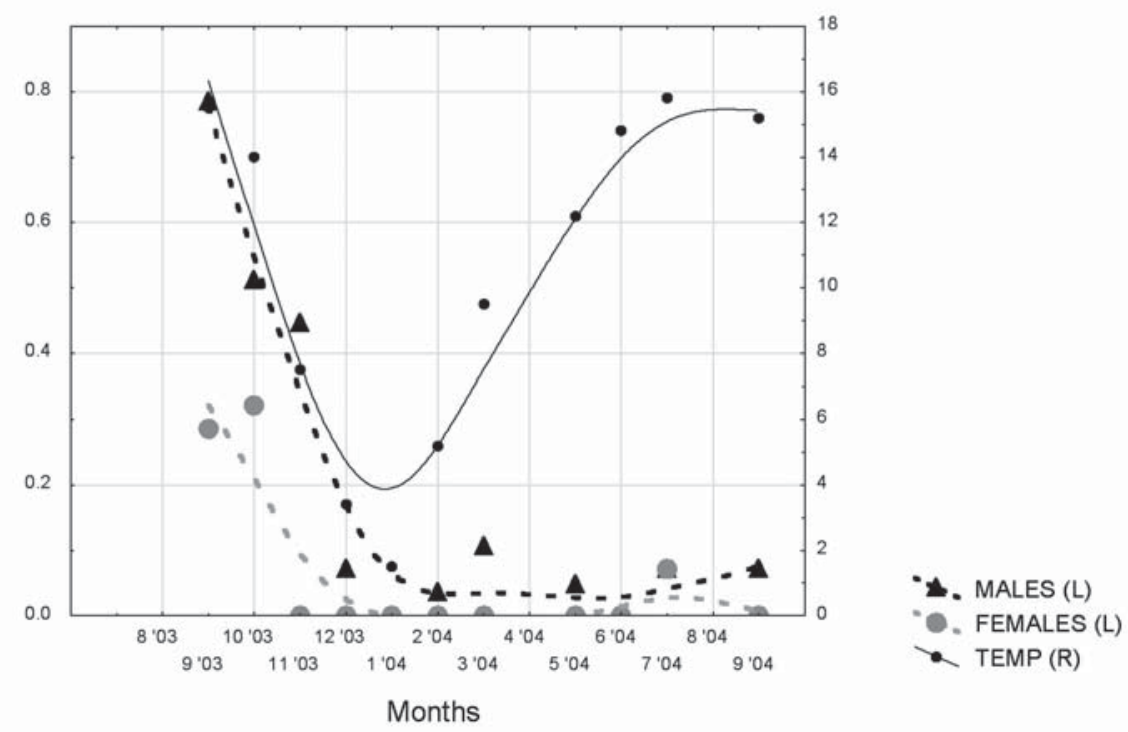

Figure 4

Relation between CPUE and the water temperature (measured during survey) on Site 3 (lower site).

\section{Figure 4}

Relation entre CPUE et température de l'eau (mesurée pendant l'étude) sur le site 3 (partie inférieure).

\section{Table VII}

Significant $p$ values for differences in CPUE between months.

Tableau VII

Valeurs significatives de $p$ pour les différences de CPUE entre les mois.

\begin{tabular}{|c|c|c|c|c|}
\hline $\begin{array}{c}\text { Year and } \\
\text { Month }\end{array}$ & $\begin{array}{c}\text { Males Site 1 } \\
\text { August 2003 }\end{array}$ & $\begin{array}{c}\text { Females Site 1 } \\
\text { August 2003 }\end{array}$ & $\begin{array}{c}\text { Females Site 2 } \\
\text { August 2003 }\end{array}$ & $\begin{array}{c}\text { Females Site 3 } \\
\text { October 2003 }\end{array}$ \\
\hline 200308 & n.s. & n.s. & n.s. & n.s. \\
\hline 200309 & n.s. & n.s. & 0,00015 & n.s. \\
\hline 200310 & 0,00032 & 0,00037 & n.s. & n.s. \\
\hline 200311 & 0,00021 & 0,00020 & 0,00018 & 0,03150 \\
\hline 200312 & 0,00059 & 0,00071 & 0,00303 & n.s. \\
\hline 200401 & 0,00059 & 0,00071 & 0,00303 & n.s. \\
\hline 200402 & 0,00059 & 0,00071 & 0,00303 & n.s. \\
\hline 200403 & 0,00059 & 0,00071 & 0,01228 & n.s. \\
\hline 200405 & 0,00191 & 0,00023 & 0,00031 & n.s. \\
\hline 200406 & 0,00304 & 0,00103 & 0,00303 & n.s. \\
\hline 200408 & n.s. & n.s. & n.s. & n.s. \\
\hline 200409 & n.s. & 0,00236 & 0,01228 & n.s. \\
\hline
\end{tabular}


2003 compared with September 2003, period from November 2003 till June 2004 and September 2004 ( $p$ <.05). On the Site 3 only significant decrease was in the number of females in November 2003 compared with October $2003(p<0.05)$.

Correlations between CPUE on the Site 3 and values of physical and chemical parameters (measured monthly) of water were calculated. CPUE for males was significantly positively correlated with total and organic nitrogen content $(r=0.80 p=0.009, r=0.91$, $\mathrm{p}=0.001$ respectively), and negatively with $\mathrm{pH}(r=-0.763, \mathrm{p}=0.017)$. CPUE for females was significantly positively correlated with organic nitrogen content $(r=0.746, p=0.021)$ and negatively with conductivity of water $(r=-0.68, p=0.044)$.

Visible physiological stages of crayfish were recorded during the research period and they are shown in Table VIII. Crayfish were active throughout the whole year. The lowest temperature on all three sites was in January, and crayfish activity was recorded even during that period. On the $5^{\text {th }}$ of January 2004 one male was caught in the hand made trap covered with ice, while water temperature was only $1^{\circ} \mathrm{C}$.

\section{Table VIII}

Annual cycle of some physiological functions per months. $X$ is a real finding, $X$ is presumption based on a real finding.

\section{Tableau VIII}

Apparition de quelques fonctions physiologiques le long de l'année pendant l'étude. $X$ représente un résultat confirmé, $x$ une présomption.

\begin{tabular}{|c|c|c|c|c|c|c|c|c|c|c|c|c|c|c|}
\hline Month & 8 & 9 & 10 & 11 & 12 & 1 & 2 & 3 & 4 & 5 & 6 & 7 & 8 & 9 \\
\hline Year & ‘03 & ‘03 & ‘03 & ‘03 & ‘03 & ‘04 & ‘04 & ‘04 & ‘04 & ‘04 & ‘04 & ‘04 & ‘04 & ‘04 \\
\hline Activity & $x$ & $\mathbf{x}$ & $x$ & $\mathbf{x}$ & $x$ & $\mathbf{x}$ & $x$ & $x$ & $x$ & $x$ & $\mathbf{x}$ & $\mathbf{x}$ & $\mathbf{x}$ & $\mathbf{x}$ \\
\hline Moulting & $x$ & $\mathbf{X}$ & $x$ & $x$ & & & & & & & & & $\mathbf{x}$ & $\mathbf{x}$ \\
\hline $q$ cement glands & & $\mathbf{x}$ & $\mathbf{x}$ & $\mathbf{x}$ & & & & & & & & & & \\
\hline of mating & & & & $\mathbf{x}$ & & & & & & & & & & \\
\hline 우 우 external eggs & & & & & $x$ & $x$ & $x$ & $x$ & $x$ & $x$ & $x$ & $x$ & & \\
\hline juveniles $1^{\text {st }}$ stage & & & & & & & & & & & & $x$ & & \\
\hline juveniles $3^{\text {rd }}$ stage & & & & & & & & & & & & & $\mathbf{x}$ & \\
\hline
\end{tabular}

Moulting was recorded for the first time in August in both years, and it continued till November in the year 2003. During the research we sometimes found crayfish and their exuvia in hand made traps.

Females with visible cement glands were recorded from September till November. The smallest female with visible cement glands was caught on the $1^{\text {st }}$ of October 2003 on the Site 1 and it had cephalothorax length of $3.48 \mathrm{~cm}(T L=7.13 \mathrm{~cm})$. Mean cephalothorax length of females with visible cement glands was $4.96 \mathrm{~cm}(T L=9.86 \mathrm{~cm})$.

Mating occurred in November. On the $10^{\text {th }}$ of November 2003 on the Site 3 male and female, with remains of spermatophores on their abdomens, were caught in LiNi trap.

Females with external eggs were caught during May and June. Only one female with two juveniles (cephalothorax length of $4.41 \mathrm{~cm}$ ) was caught, on the $1^{\text {st }}$ of August 2004, on the Site 1. Juveniles total length was 1.53 and $1.40 \mathrm{~cm}$, and they were at the $3^{\text {rd }}$ moulting stage. 


\section{DISCUSSION AND CONCLUSION}

Our data on the activity of Astacus astacus in the Orljava River are based on the crayfish caught by traps and therefore provide information only on the trapped proportion of the populations. Trappability (activity) is mainly connected with food searching (BROWN and BOWLER, 1977), but might also fluctuate in connection to the other factors such as water temperature, light conditions etc. (ABRAHAMSSON, 1983).

In our study, like in the study by BROWN and BOWLER (1977), there was always higher number of trapped males than females regardless of the season (Table III) (Figures 2-4). Equal number of males and females was caught only on the Site 1 in October 2003 (m:f = 6:5) and August 2004 ( $\mathrm{m}: f=9: 8$ ). Similar results were presented by LUCIĆ (2004); in her study on the population of the noble crayfish in the Vukovina Lake, total sex ratio was 2.88:1 (m: f); from June till September number of males and females was almost equal 1.15:1 (m: f), while during May and from October till January males prevailed in the catch. More balanced sex ratio $(\mathrm{m}: \mathrm{f}=1.09: 1)$ was found in the Velika Paklenica Stream population (MAGUIRE et al., 2002). In their study, males were dominant during July, and females during August and September. ACKEFORS (1999) divided a year into two parts depending on females'activity and sex ratios; from November till June males were dominant with sex ratio from 6:1 ( $\mathrm{m}$ : f) to 16:1 (m: f), and from July till October sex ratio was close to 1 . From November till June only females without external eggs were caught. It is known that lower number of females trapped during the egg bearing period is a consequence of berried females being trap shy (ACKEFORS, 1999; SKURDAL and TAUGBØL, 2002). In addition, our results on sex ratio could be explained with the BROWN and BOWLER (1977) suggestion that all females "avoid" traps irrespective of reproductive state, so sex ratio does not always represent the real situation within the population.

In general, on all three sites males were larger than females (Table IV). Cephalothorax length differed significantly between the two sexes due to sexual dimorphism (ABRAHAMSSON, 1966; SKURDAL and TAUGBØL, 2002). MAGUIRE et al. (2002) and LUCIĆ (2004) also found statistically significant differences between males and females in both cephalothorax and total length.

BOHL (1997) pointed out that the proportion of damaged crayfish in a population could indicate existence of violation by predators. In our study the biggest proportion of damaged crayfish was recorded on the Site 1 (Table V), where we haven't recorded presence of predatory fish (or any other predator), so we can exclude predation as a cause of injuries. At the same time, population density on the Site 1 was higher than on the sites 2 and 3 (Table $\mathrm{VI}$ ). Explanation for the high percentage of injuries (specially claw injuries) could be in aggressive interference between crayfish, as it was shown by BOHL (1997) who was studding a dense population of Austropotamobius pallipes. In our research, we also observed that damaged claws were the most common injury both at males and females (Table V), so we could assume that claw injuries were consequence of violent behaviour between crayfish. Similar results were obtained by SKURDAL et al., 1988, who found that the biggest proportion of chiliped loss was in dense populations where crayfish were not exploited.

Other possible reasons of injuries were difficulties during moulting or rolling stones during torrents. While in the study by LUCIĆ (2004), percentage of injured males was higher than percentage of injured females $(29.17 \%$ and $9.7 \%$, respectively), in our study, overall percentage of injured males and females was similar (36.35\% and $33.43 \%$, respectively).

It is known that crayfish presence (among other factors) is strongly dependent on the structure of the stream bottom (NIEMI, 1977; BOHL, 1987; LAURENT, 1988; REYNOLDS, 2002) and higher population density is expected where greater morphometric and structural variability exists (BOHL, 1997). Composition and size of the bottom 
substrate have the greatest structural variability on the Site 1 (Table I), and that is probably the reason why this site had the highest population density.

Recorded physical and chemical parameters of water (Table II) were similar to values recorded for the noble crayfish habitats (NIEMI, 1977; BOHL, 1987; ACKEFORS, 1999; MAGUIRE et al., 2002; LUCIĆ, 2004).

Since most of the information on a life cycle of noble crayfish is based on the research made on the northern European populations, one of the aims of this research was to investigate if Croatian populations of $A$. astacus follow the same pattern and time frame of life cycle. However, some data on the Croatian noble crayfish population exist (Table IX). Study made by LUCIĆ (2004) provides data for population of $A$. astacus in the Vukovina Lake near Zagreb (continental part of Croatia), while population of $A$. astacus in the Velika Paklenica Stream (in the Adriatic Sea drainage) was described by MAGUIRE et al. (2002). In Table IX these data are presented in comparison to data gathered by ACKEFORS (1999) for Swedish population, as well as with data collected during our research on the population of the Orljava River.

Our results on the crayfish activity based on the number of trapped crayfish (Table VIII) (Figures 2-4) showed that crayfish were active during the whole year, but as expected, their activity was lower during winter period. Our record of active crayfish at water temperature of $1^{\circ} \mathrm{C}$ is similar to findings for $A$. astacus in a small lake in Sweden

Table IX

Data on the occurrence of different phases of life cycle of Astacus astacus from research performed by us in comparison to other authors: ACKEFORS (1999), MAGUIRE et al. (2002) and LUCIĆ (2004). The results are presented with letters 0 (Orljava River), S (Sweden), P (Paklenica Stream) and V (Vukovina Lake).

\section{Tableau IX}

Apparition tout au long de l'année des différentes phases du cycle annuel d'Astacus astacus lors de notre étude et dans les études de : ACKEFORS (1999), MAGUIRE et al. (2002) et LUCIĆ (2004). Les résultats sont présentés avec les lettres $\mathbf{O}$ (Rivière Orljava), S (Suède), P (Fleuve Paklenica) et V (Lac Vukovina).

\begin{tabular}{|c|c|c|c|c|c|c|c|c|c|c|c|c|}
\hline Month & 8 & 9 & 10 & 11 & 12 & 1 & 2 & 3 & 4 & 5 & 6 & 7 \\
\hline \multirow{2}{*}{ Activity } & PV & PV & $\mathrm{V}$ & $\mathrm{V}$ & $\mathrm{V}$ & V & & & $P$ & PV & PV & PV \\
\hline & $\mathrm{O}$ & $\mathrm{O}$ & $\mathrm{O}$ & $\mathrm{O}$ & $\mathrm{O}$ & $\mathrm{O}$ & $\mathrm{O}$ & $\mathrm{O}$ & & $\mathrm{O}$ & $\mathrm{O}$ & $\mathrm{O}$ \\
\hline \multirow{2}{*}{ Moulting } & SPV & SPV & SV & & & & & & & $\mathrm{V}$ & PV & SPV \\
\hline & $\mathrm{O}$ & $\mathrm{O}$ & $\mathrm{O}$ & $\mathrm{O}$ & & & & & & & & \\
\hline \multirow{2}{*}{ $\uparrow$ Cement glands } & $\mathrm{V}$ & SPV & SV & $S$ & & & & & & & & \\
\hline & & $\mathrm{O}$ & $\mathrm{O}$ & $\mathrm{O}$ & & & & & & & & \\
\hline \multirow{2}{*}{ of $q$ Mating } & & & $S$ & $S$ & & & & & & & & \\
\hline & & & & $\mathrm{O}$ & & & & & & & & \\
\hline \multirow[b]{2}{*}{ 우 External eggs } & & & $S$ & $S$ & $S$ & $S$ & $S$ & SP & SP & SP & SP & \\
\hline & & & & & & & & & & 0 & & \\
\hline \multirow[b]{2}{*}{ Hatching } & & & & & & & & & & & $P$ & $\mathrm{SP}$ \\
\hline & & & & & & & & & & & & 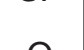 \\
\hline
\end{tabular}


(ACKEFORS, 1999). He found a few active crayfish in January while water temperature was just above $0^{\circ} \mathrm{C}$. ŚMIETANA (2003) also found numerous narrow-clawed crayfish (Astacus leptodactylus) in Poland, active throughout the whole winter period. Different results were obtained by LUCIĆ (2004) and TROSCHEL et al. (1995). They found that the lowest temperatures on which noble crayfish and stone crayfish were active were $4.5^{\circ} \mathrm{C}$ and $5^{\circ} \mathrm{C}$, respectively. In our study crayfish activity was the highest from August till October, probably as consequence of females becoming more active after releasing the juveniles and both sexes preparing for mating. It is known that crayfish activity is influenced by water temperature (KIVIVUORI, 1977; BOHL, 1987; MAGUIRE et al., 2002). Higher temperatures can raise an animal's locomotion and metabolic rates and it is likely that the trappability is greater at higher temperatures (ACKEFORS, 1999). A positive correlation between the water temperature and the number of animals caught was found for Austropotamobius torrentium (TROSCHEL et al, 1995; MAGUIRE, 2002), as well as for $A$. astacus (MAGUIRE et al., 2002; LUCIĆ, 2004). In our research, CPUE was also positively correlated with the water temperature (Figures 2-4). However only on the Site 1 this correlation is statistically significant. Absence of significant correlations on sites 2 and 3 is probably consequence of general decline in number of crayfish trapped. After water temperature increased in the year 2004, simply crayfish were scarce and there was not many crayfish whose activity would increase and influence on significance of correlation. In accordance with TROSCHEL et al. (1995) and MAGUIRE et al. (2002), we found that the amount of activity in spring did not increase proportionally to the raise of the water temperature, but it seems likely that the raise of temperature in early spring was an initiator of their activity (Figures 2-4).

CPUE dramatically decreased on sites 2 and 3 in the year 2004, compared to the year 2003 (Figures 3 and 4) (Table VII). Decrease was also observed on the Site 1, but not with the same intensity (Figure 2). Declines in the population number are usually attributed to: (1) the deterioration of water quality and habitat destruction, (2) direct competition with non-native crayfish and (3) the crayfish plague (BRAMARD et al. 2003). None of these reasons could explain the observed population decline in our study. DEMERS et al. (2004) detected decline in the population of $A$. pallipes from Western France. In their case, CPUE dropped to one tenth, and decline was explained as a consequence of low oxygen concentration (average $6.2 \mathrm{mg} / \mathrm{l}$ ) and high water temperature (maximum between $19^{\circ} \mathrm{C}$ and $29^{\circ} \mathrm{C}$ ). Contrary to these findings, HOLDICH et al. (2005) has shown that $A$. pallipes can also be found in muddy habitats, which are usually associated with low oxygen concentrations. In our case, water temperatures, as well as oxygen concentrations (minimum $8 \mathrm{mg} \mathrm{l}^{-1}$ ) were within the range that is suitable for noble crayfish (BOHL, 1987). Thus decrease in population density on sites 2 and 3 cannot be explained by those physical and chemical parameters. Normal fluctuations in crayfish density are also known (REYNOLDS, 2002), so it is possible that recorded declines in our population density were consequence of natural fluctuations in the population. As study on those populations is still ongoing, we suppose that we will get more useful information about fluctuation in population number that will help us explain declines.

According to the literature (SKURDAL and TAUGBØL, 2002), the first moulting period for males and unberried females normally occurs in mid spring or early summer, depending on the climate. The second moulting period occurs in late summer or early autumn, at which time the females that were berried join in moulting. It is known that during moulting animals are less active (REYNOLDS, 2002). We found freshly moulted crayfish only from August to November (the second moulting period), since we have presumably missed the first moulting period. ACKEFORS (1999) found moulting crayfish from July till October what is one month less then in the Orljava River populations. Prolongation of moulting period in this southern region could be explained with higher water temperature in autumn and thus longer period of activity. MAGUIRE et al. (2002) found that moulting in coastal stream populations started in June and lasted till September, while LUCIĆ (2004) found 
that moulting in the lake population started even earlier, in May, and lasted till October (Table IX). Finding of a freshly moulted crayfish inside the hand made trap indicates that crayfish possibly used this trap type as a shelter.

Occurrence of cement glands clearly defines sexually mature females (GRANDJEAN et al., 1997a, 1997b). The smallest female with developed cement glands that we caught was $7.13 \mathrm{~cm}$ long and that is similar to findings of other authors (TAUGBØL et al., 1988; WESTIN and GYDEMO, 1989; ACKEFORS, 1999). ACKEFORS (1999) found females with active cement glands from September till November, and that is similar to results for our population.

We recorded occurrence of mating in November. In Sweden mating occurred during September and October (WESTIN and GYDEMO, 1986) and October and November (ACKEFORS, 1999), while in Finland during September and October (HUNER and LINDQVIST, 1986). It can be therefore concluded, that in Croatia mating starts later in comparison to the Northern Europe, most probably due to prolonged period of higher water temperatures in the autumn.

During our research we caught only two females with external eggs (in May and June). Similarly, MAGUIRE et al. (2002) found external eggs till June, while LUCIĆ (2004) did not find any female with external eggs. As said before, egg-bearing females are less active, and therefore their catchability is lower so recorded percentages under represent the actual number of berried females in the populations. In northern $A$. astacus populations (ACKEFORS, 1999) females also carried eggs till June.

The appearance of juveniles in the $3^{\text {rd }}$ stage was recorded on the $1^{\text {st }}$ August 2004 (Table VIII) and that means that hatching probably occurred in July (Table IX). Eggs were incubated for eight months, what is one month less then in the Swedish population studied by ACKEFORS (1999) - hatchlings occurred in July, after nine months of incubation, and similar to results from SKURDAL and TAUGBØL (2002) - the egg incubation period lasted for 8-9 months.

The results of our research show that studied Croatian populations of $A$. astacus follow the same pattern of life cycle as Northern European populations, but the time frame is to some extent different probably due to the differences in the climate.

\section{ACKNOWLEDGEMENT}

We would like to thank the referees for their useful comments and suggestions that helped to improve this paper.

\section{REFERENCES}

ABRAHAMSSON S.A.A., 1966. Dynamics of an isolated population of the crayfish Astacus astacus Linné. Oikos, 17, 96-107.

ABRAHAMSSON S.A.A., 1983. Trappability, locomotion and diel pattern of activity of crayfish $A$. astacus and $P$. leniusculus. Freshwater Crayfish, 5, 239-253.

ACKEFORS H.E.G., 1999. Observations on the Yearly Life Cycle of Astacus astacus in a Small Lake in Sweden. Freshwater Crayfish, 12, 413-429.

BOHL E., 1987. Comparative studies on crayfish brooks in Bavaria (Astacus astacus L., Austropotamobius torrentium Schr.). Freshwater Crayfish, 7, 287-294.

BOHL E., 1997. An isolated population of the white-clawed crayfish (Austropotamobius pallipes) in the principality of Liechtenstein. Bull. Fr. Pêche Piscic., 347, 701-712. 
BRAMARD M., BACHELIER E., DUMAS J-C., FOURNIER C., BROUSSARD E., ROBIN O., GRANDJEAN F., 2003. Evolution of the distribution of native and exotic species for twenty five years in Poitou-Charentes region (France) and causes of regression of Autropotamobius pallipes. Abstract from The endangered native crayfish Austropotamobius pallipes, Bioindicator and heritage species, 2, Craynet, Kilkenny, Ireland.

BROWN D.J., BOWLER K., 1977. A population study of the British freshwater crayfish Austropotamobius pallipes (Lereboullet). Freshwater Crayfish, 3, 33-49.

CUKERZIS, J.M., 1988. Astacus astacus in Europe. In: HOLDICH D.M., LOWERY R.S. (eds.) Freshwater Crayfish: Biology, Management and Exploitation, 309-340, Croom Helm, London.

DEMERS A., TROUILHE M-C., SOUTY-GROSSET C., BACHELIER E., GRANDJEAN F., 2004. Impact of a heat wave on crayfish populations in a region of Western France. Abstract from the European native crayfish in relation to land-use and habitat deterioration, Craynet, Innsbruck, Austria.

GRANDJEAN F., ROMAIN D., AVILA-ZARZA C., BRAMARD M., SOUTY-GROSSET C., MOCQUARD J.P., 1997a. Morphometry, sexual dimorphism and size at maturity of the white-clawed crayfish Austropotamobius pallipes pallipes (Lereboullet) from a wild French population at Deux-Sèvres (Decapoda, Astacidae). Crustaceana, 70 (1), 31-44.

GRANDJEAN F., ROMAIN D., SOUTY-GROSSET C., MOCQUARD J.P., 1997b. Size at sexual maturity and morphometric variability in three populations of Austropotamobius pallipes pallipes (Lereboullet, 1858) according to a restocking strategy. Crustaceana, 70, 454-468.

HOLDICH D.M., FOSTER J., PEAY S., BRICKLAND J., 2005. Where does the white-clawed crayfish live in muddy habitats? Abstract from the Craynet Final Conference, 20, Craynet, Florence, Italy.

HUNER J.V., LINDQVIST O.V., 1986. A stunted crayfish Astacus astacus population in central Finland. Freshwater Crayfish, 6, 156-165.

KIVIVUORI L., 1977. Temperature acclimation of the motor activity in the crayfish Astacus astacus. Freshwater Crayfish, 4, 265-274.

LAHTI E., LINDQUIST O.V., 1983. On the reproductive cycle of the crayfish Astacus astacus L. in Finland. Freshwater Crayfish, 5, 18-26.

LAURENT P.J., 1988. Austropotamobius pallipes and A. torrentium, with observations on their interactions with other species in Europe. In HOLDICH D.M., LOWERY R.S. (eds.), Freshwater crayfish: Biology, Management and Exploitation, 83-114, Croom Helm, London.

LUCIĆ A., 2004. Physiological characteristics of three species of the freshwater crayfish from the Astacidae family. $\mathrm{PhD}$ thesis (in Croatian with English abstract), 122 pages, University of Zagreb, Croatia.

MAGUIRE I., 2002. Family Astacidae in north-west Croatia. PhD thesis (in Croatian with English abstract), 128 pages, University of Zagreb, Croatia.

MAGUIRE I., ERBEN R., KLOBUČAR G.I.V., ŠTAMBUK A., HUDINA S., GALIĆ N., ĐURIĆ P., 2002. Riječni rak (Astacus astacus) na području NP Paklenica. Study report for NP Paklenica, 16 pages. 
MAGUIRE I., GOTTSTEIN-MATOČEC S., 2004. The distribution pattern of freshwater crayfish in Croatia. Crustaceana, 77 (1), 25-49.

NARODNE NOVINE 70, 2005. Zakon o zaštiti prirode.

NARODNE NOVINE 07, 2006. Pravilnik o proglašavanju divljih svojti zaštićenim i strogo zaštićenim.

NIEMI A., 1977. Population studies on the crayfish Astacus astacus L. in the river Pyhäjoki, Finland. Freshwater Crayfish, 3, 81-94.

REYNOLDS J.D., 2002. Growth and reproduction. In: HOLDICH D.M. (ed.), Biology of Freshwater Crayfish, 152-192, Blackwell Science, Oxford.

SKURDAL J., TAUGBØL T., FJELD E., QVENILD T., 1988. Chiliped loss in Astacus astacus. Freshwater Crayfish, 7, 47-51.

SKURDAL J., TAUGBØL T., 2002. Astacus. In: HOLDICH D.M. (ed.) Biology of Freshwater Crayfish, 467-510, Blackwell Science, Oxford.

ŚMIETANA P., 2003. Migration and distribution of narrow-clawed crayfish Astacus leptodactylus Esch. in the Lake Bylice, Wołczkowo. Oficyna In Plus: 106-110 (in Polish with English abstract).

TAUGBØL T., SKURDAL J., FJELD E., 1988. Maturity and fecundity of Astacus astacus females in Norway. Freshwater Crayfish, 7, 107-114.

TROSCHEL H.J., SCHULZ U., BERG R., 1995. Seasonal activity of stone crayfish Austropotamobius torrentium. Freshwater Crayfish, 10, 196-199.

WESTIN L., GYDEMO R., 1986. Influence of light and temperature on reproduction and moulting frequency in the crayfish, Astacus astacus. Aquaculture, 52, 43-50.

WESTIN L., GYDEMO R., 1989. Variation in sex ratio in the noble crayfish Astacus astacus: reflection of the yearly activity changes. Freshwater Crayfish, 7, 115-120.

WESTMAN K., PURSIAINEN M., VILKMAN R., 1978. A new folding trap model which prevents crayfish from escaping. Freshwater Crayfish, 4, 235-242.

WOODIWISS, F. S., 1964. The biological system of stream classification used by the Trent River Board. Chemistry and Industry, 11, 443-447. 



\section{REMERCIEMENTS :}

Nous tenons à remercier chaleureusement l'ensemble des relecteurs ayant contribué à la publication du BFPP pendant l'année 2006 :

Our warmest thanks to all the reviewers who have greatly contributed to the publications of the BFPP during the year 2006:

Jan BAER, Vassilis BAKOPOULOS, Sanja BARIC, Roger BERGSTED, Eric BOHL, Thierry BOUJARD, Christian BRY, José CARRAL, Daniel CATTAERT, Thomas CHANGEUX, Edo D'AGARO, Andréanne DEMERS, Javier DIEGUEZ-URIDIBEONDO, Yves DESAUNAY, Zdenek DÚRIS, Avi ELDAR, Sarah FRATINI, Leopold FÜREDER, Stuart R. GELDER, Francesca GHERARDI, Piero GIULIANINI, Frédéric GRANDJEAN, Nicolas GOUIN, Patrick HAFFNER, Paula HENTTONEN, David HOLDICH, Jay V. HUNER, Jussila JAPO, Philippe KEITH, Max KELLER, Pavel KOZAK, Carlo R. LARGIARDĖR, Pierre LAURENT, Marc LEGENDRE, Mario LEPAGE, Ivanna MAGUIRE, Ari MANNONEN, Charles MÉLARD, Jean MORIN, Yann MOREAU, Pietro Angelo NARDI, Alix NIHOUARN, Pierre NÖEL, Birgit OIDTMANN, Jean-Marc OLIVIER, Giuliana PARISI, Stephanie PEAY, Didier PONT, JeanPierre PROTEAU, Barbara RENAI, Przemyslaw ŚMIETANA, Julian REYNOLDS, Charles ROQUEPLO, Jean-Marc ROUSSEL, Maria SAEZ-ROYUELA, Massimiliano SCALICI, Christoph SCHUBART, Holger SCHULZ, Ralf SCHULZ, Peter SIBLEY, Olivier SIMON, Fred SLATER, Ondrej SLAVIK, Catherine SOUTY-GROSSET, Todd STEEVES, Thomas STUCKI, Marc SUQUET, Evelyne TALĖS, Trond TAUGBØL, Ian WINFIELD, Serena ZACCARA. 